\title{
STUDENTU NUOMONĖS APIE STUDIJŲ DALYKŲ DËSTYMO KOKYBĘ TYRIMO DUOMENŲ VERTINIMO METODOLOGINIS PAGRINDIMAS
}

\author{
Giedrè Judita Rastauskienė, Ina Marija Šeščilienė, Ilona Tilindienė \\ Lietuvos kūno kultūros akademija, Kaunas, Lietuva
}

Giedrė Judita Rastauskienė. Socialinių mokslų magistrè. Lietuvos kūno kultūros akademijos Sporto biomechanikos, inžinerijos ir informatikos katedros asistentė. Mokslinių tyrimų kryptis — socioedukacinių tyrimų analizè, sociometrija.

\begin{abstract}
SANTRAUKA
Šiame straipsnyje pateikiamas studentu nuomonès apie studiju dalyku dèstymo kokybę tyrimo duomenu vertinimo metodologinis pagrindimas, atliktas statistiniais metodais, naudojant balinę matavimo skalę, duomenu standartizavima ir faktoriu analizę, kuri leidžia išskirti du dèstymo kokybès faktorius: pirma — dalyko ypatybes, antra - dèstytojo savybes.
\end{abstract}

Déstymo kokybę nagrinèjome studento poreikiu aspektu, kai dèstymo kokybé yra laikoma studiju paslaugos tiesioginio vartotojo poreikius tenkinančiu rezultatu, atitinkančiu jo suvokiamus dèstymo paslaugos modelio privalumus ir trūkumus. Atsižvelgdami i sudètingq ir nevienareikšmiška dėstymo kokybès traktavima, nagrinëjome tik tuos dalyku dèstymo kokybès indikatorius, kurie, mūsu nuomone, gali daryti įtaka studentu igyjamoms kompetencijoms.

Pasibaigus 2005-2006 mokslo metams, buvo apklausti Lietuvos kūno kultūros akademijos (LKKA) bakalauro studiju pakopos 1077 dieninès ir neakivaizdinès studijuformos I_IV kurso studentai, kurie išreiškè nuomonę apie studijuotu dalyku dèstymo kokybès indikatorius. Studentu nuomonés apie studiju dalyku dèstymo kokybę tyrimo duomenu vertinimo metodologinis pagrindimas leido nustatyti ir interpretuoti LKKA bakalauro dieninès ir neakivaizdines formos studentu, kaip studiju paslaugos tiesioginiu vartotoju, nuomonę apie 2005-2006 m. m. studiju dalyku dèstymo kokybę.

Gauti rodikliai: studiju dalyku aktualumo profesijai ir pasitenkinimo dèstytojo savybèmis rodikliai gali būti naudojami atskiru studiju dalyku dèstymui ìvertinti, tačiau turi büti nagrinejami kartu su kitu to paties dalyko dèstytoju dèstomu dalyku rodikliais ir igauna prasmę tik tada, kai naudojami kaip priemonè dèstymo procesui tobulinti.

Tyrimo rezultatai neatskleidžia dèstymo kokybès, tačiau leidžia išsamiai analizuoti subjektyviq studentu nuomonę, patikrinti parengta tyrimo duomenu apdorojimo ir interpretavimo metodika. Vienas iš autoriu tikslu — paskatinti akademinès bendruomenès diskusija apie dèstymo kokybès būklę.

Raktažodžiai: dèstymo kokybè, kokybès indikatoriai, dèstymo kokybès tyrimo metodologija.

\section{IVADAS}

K artu su Europa Lietuva eina link žiniomis grindžiamos visuomenès ir tampa globacinès, technologinès ir kultūrinès erdvès dalimi. Europos komisija $2000 \mathrm{~m}$. kovo $24 \mathrm{~d}$. Lisabonoje pažymèjo pagrindinius Europos Sajungos politikos momentus. Ji patvirtino, kad Europa eina į žiniu amžiu — keisis darbo, mokymosi, paties gyvenimo pobūdis, ir tai turès didžiulę įtaką kultūriniam bei socialiniam visuomenès, individo gyvenimui. Šiuolaikinèje visuomenejje kartą igytas išsilavinimas negarantuos sèkmingos karjeros. Plètodama šias nuostatas, Europos komisija $2000 \mathrm{~m}$. spalio $30 \mathrm{~d}$. paskelbė mokymosi visą gyvenimą memorandumą. Europos vieningos mokymosi erdvès idejja, konkurencija tarptautinejje erdveje, masinis mokymasis, studentų mobilumas, naujos studijų formos skatina universitetus susirūpinti studijų kokybe.

Studijų kokybè vertinama daugelyje šalių, kuriose idiegtos arba dar tik diegiamos mokslo ir studijų kokybės laidavimo sistemos. Lietuvos švietimo sistemai integruojantis i pasaulinę švietimo erdvę, 
vienas iš aukštojo mokslo studijų prioritetinių uždavinių - nuolatinis studijų kokybès vertinimas, tobulinimas ir kokybės garantavimas. Studijų kokybė garantuojama visu pirma pačios aukštosios mokyklos pastangomis, kurios orientuotos i Aukštojo mokslo istatymo ir kitų teisès aktu reikalavimus, t. y. vidine organizacijos studiju kokybès laidavimo sistema. Vidinis studijų kokybės garantavimas kiekvienoje institucijoje remiasi sistemingu studiju kokybès būklės nustatymu ir ívertinimu - savianalize.

Svarbūs visi studiju kokybès kriterijai, tačiau vienas iš svarbiausiu — dèstymo kokybè - sudètinè studijas teikiančios institucijos vertinimo dalis. Kokybès procesų valdymo atžvilgiu dėstymo procesas - studiju paslaugos grandis, kurios prioritetinius kokybės valdymo objektus turime apibrèžti. Tai studijų programos, studijų dalykai ir dèstytojai, tiesiogiai dalyvaujantys šių studiju dalyku programų rengimo ir dèstymo procese.

Tradicinis studijų kokybès traktavimas turi atitikti griežtus reikalavimus: turi būti vykdoma stojančiuju atranka, vertinamas mokymo turinio sudètingumas ir pasiekimai. Tiesiog reikètu išsiaiškinti, ar standartai ir numatyti reikalavimai neriboja studiju proceso dalyvių (tiek desstytojų, tiek studentu) kūrybiškumo ir inovacijų. Požiūris, kai kokybė suprantama kaip klaidų nedarymas, dažniau sutinkamas gamybos paslaugų srityje. Studijų procese sąveikauja žmoniškieji veiksniai, todèl klaidos neišvengiamos. Požiūriai ị kokybę, kaip organizacijos misijos vykdymą arba kaip i transformaciją, yra egzistenciniai ir idealistiniai, susiję su požiūriu į švietimo institucijas kaip besimokančias organizacijas. Populiarejja požiūris, kai kokybe traktuojama kaip vartotoju poreikiu ir lūkesčių tenkinimas, akcentuojama, kad kokybė yra siekis pažinti vartotoją, numatymas, kaip gerinti ir tobulinti teikiamas paslaugas, gebejjimas konkuruoti rinkoje. Ypač svarbus yra subjektyvus kokybès vertinimas - vartotojo pasitenkinimas, kuris turi atskleisti daugeli gyvenimo sričių: mokymąsi, laisvalaikị ir socialinius ryšius (Valiuškevičiūte ir kt., 2004; Stake, Cisneros-Cohernour, 2005).

Aukštojo mokslo sistemoje itemptai diskutuojama apie tai, kas yra aukštojo mokslo vartotojai: studentai, darbdaviai ar valstybè, o organizacijose, kurios teikia paslaugas, tokiose kaip draudimo bendrovès, medicinos istaigos, mokymo istaigos, neaišku ne tik kas yra vartotojas, bet ir kas yra paslaugos kokybė. Kokybę nustatyti sudètinga, kadangi pati kokybès sąvoka yra pakankamai abstrakti. Vartotojo požiūriu kokybė nèra sava- rankiškas, izoliuotas aukščiausio lygio standartas. Don F. Westerheijden (2005) teigia, kad „lūkesčiu lygis dažniausiai skiriasi nuo subjekto patirties: kuo geresnè kokybė buvo anksčiau, tuo labiau ji turi gerèti, kad patenkintu būsimus lūkesčius“".

Dėstymo kokybę studijų proceso dalyvis suvokia kaip sudettingą, daugialypę, nuolat kintančią. Kiekvienas ją suvokia skirtingai, todèl dèstymo kokybės tyrimų rezultatas priklauso nuo to, ką laikome dėstymo kokybe ir kokiu aspektu ją tiriame. Iki šiol nèra patvirtinta nè vienos moksliškai pagristos dėstymo kokybès rodiklių nustatymo sistemos, nèra ir vieningos visuotinai priimtos dèstymo kokybès tyrimo duomenų vertinimo sistemos.

Atsižvelgdami ì sudètingą dèstymo kokybès traktavimą, nesutelkème dèmesio i̇ dèstytojo pareigas, asmenybės bruožus, dėstymo stilių ir metodus, studentų pasiekimus, jų akademinį ir socialini identiteta, nors tai irgi labai svarbu. Nagrinejome tik bakalauro studiju pakopos studentų nuomonę apie studijų dalyko dèstymo kokybès indikatorius, galinčius turèti itakos studentų igyjamoms kompetencijoms.

Daug diskusijų tarp tyrëjų kelia klausimai: kas turi nustatyti ir iqvertinti kokybę, kuo remiantis galima parengti vertinimo instrumenta, kokia kokybès būklès nustatymo ir vertinimo metodika. Tiriant studentų nuomonę studiju kokybès klausimais, problemų kelia ne tik tyrimo instrumento parengimas, bet ir gautų duomenų apdorojimas ir analizè. Daugelio Lietuvos tyrèjų darbuose, apibendrinant studentų nuomonès tyrimų duomenis, dažnai apsiribojama nominaline ir (ar) rangine skale, rezultatai išreiškiami procentais ir pateikiama, kiek procentu respondentų vienoki ar kitoki indikatorių vertina blogai, patenkinamai, gerai ar puikiai. Pagal pateikiamą metodologiją duomenims analizuoti naudota balinè skalè, kuri leidžia taikyti daugiau statistiniu metodų, nustatomi apibendrinti faktoriai.

Tiriamieji. $2005-2006 \mathrm{~m}$. m. buvo tiriami 1077 LKKA bakalauro pakopos visų studiju programų studentai (986 dieninès ir 91 neakivaizdinès studijų formos studentai), neatsitiktinai pasirinkti „pagrindinio masyvo“ metodu (apklausta apie pusę bakalauro pakopos studentų).

\section{TYRIMO METODAS}

Studentų nuomonei apie studijų dalyko dèstymo kokybę ivertinti buvo pasirinkti dėstymo kokybès indikatoriai, kurie sudarè aštuonių teiginiu skalę (žr. 1 lent.). 


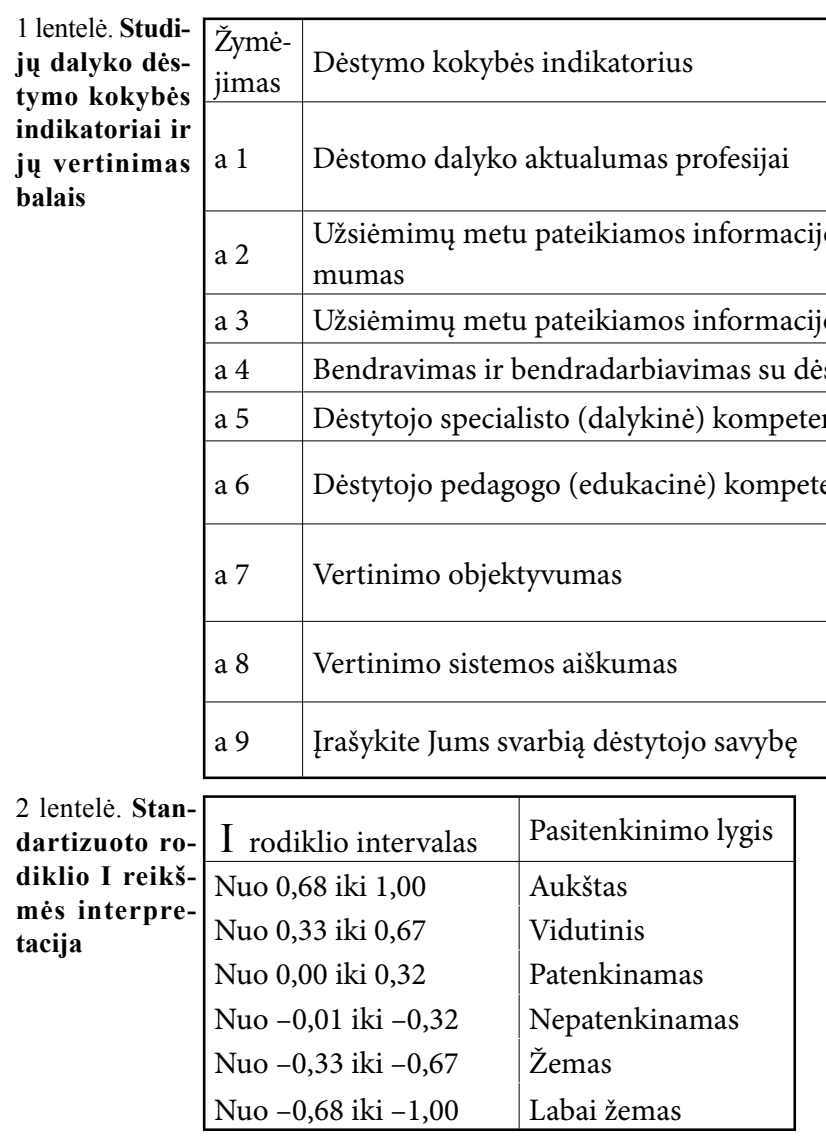

Gautos 9442 249-ies studijų dalykų 191 dèstytojo desstymo kokybès vertinimo anketos pagal anksčiau nurodytos skalès teiginius. Šiems duomenims kaupti ir apdoroti buvo sukurta informacine sistema Microsoft Access 2003 duomenu bazès pagrindu.

Informacinès sistemos loginiame modelyje kiekvienas studijų dalykas ir ji destantis destytojas buvo aprašomas aštuoniais dèstymo kokybès indikatoriais (žr. 1 lent.). Vienam indikatoriui vertinti parinkta balinè matavimo skalè, kurioje reikšmès kito: nuo visai blogai $(-3)$, blogai $(-2)$, nepatenkinamai $(-1)$, neturiu nuomonès (0), patenkinamai (1), gerai (2) iki puikiai (3). Indikatorius buvo standartizuojamas reikšmių intervale nuo -1 iki 1 . Šitaip buvo apskaičiuojamas kiekvieno studijų dalyko ir ji dèstančio desstytojo pasitenkinimo indikatoriumi rodiklis $I_{P}$ pagal formulę:

$\mathrm{I}_{\mathrm{P}}=\frac{-1 \times \mathrm{n}_{1}-0,67 \times \mathrm{n}_{2}-0,33 \times \mathrm{n}_{3}+0,33 \times \mathrm{n}_{5}+0,67 \times \mathrm{n}_{6}+1 \times \mathrm{n}_{7}}{\mathrm{n}_{1}+\mathrm{n}_{2}+\mathrm{n}_{3}+\mathrm{n}_{5}+\mathrm{n}_{6}+\mathrm{n}_{7}}$,

čia $\mathrm{n}_{1}$ - respondentu, kurie vertino visai blogai $(-3), \mathrm{n}_{2}-$ blogai $(-2), \mathrm{n}_{3}$ - nepatenkinamai $(-1), \mathrm{n}_{5}$ - patenkinamai (1), $\mathrm{n}_{6}$ - gerai (2), $\mathrm{n}_{7}$ - puikiai (3) skaičius; $-1 ;-0,67$; $-0,33 ; 0,33 ; 0,67 ; 1-$ vertinimo balo svertiniai koeficientai. Respondentų, kurie vertindami neturèjo nuomonès, skaičius $\mathrm{n}_{4}(0)$, pasitenkinimo rodiklio $\mathrm{I}_{\mathrm{p}}$ apskaičiavimui itakos neturi. Standartizuoto rodiklio I reikšmès interpretacija pateikiama
2 lentelëje. Jei pasitenkinimo žodinė interpretacija kelia abejonių, pasitenkinimo lygi galima ivvardyti ir kitais žodžiais, pavyzdžiui, labai geras, geras, pakankamas, patenkinamas, nepatenkinamas, blogas ir pan.

Pavyzdys. 12 respondentų vertino studijų dalyko aktualumą profesijai. Iš jų trys išreiškè nuomonę - visai blogai ( -3 balai), devyni - gerai ( 2 balai). Pasitenkinimo desstymo kokybès indikatoriumi rodiklis $I_{p}$ apskaičiuojamas pagal formulę:

$I_{P}=\frac{-1 \times 3-0,67 \times 0-0,33 \times 0+0,33 \times 0+0,67 \times 9+1 \times 0}{3+0+0+0+9+0}=0,25$

Kadangi $\mathrm{I}_{\mathrm{p}}=0,25$ reikšmė patenka į I rodiklio intervalą nuo 0,00 iki 0,32 (žr. 3 lent.), pasitenkinimo lygis dèstymo kokybès indikatoriumi yra interpretuojamas kaip patenkinamas.

Jei dèstymo kokybès indikatorius - užsièmimų metu pateikiamos informacijos pritaikomumą (a 2) ir naujumą (a 3), bendravimą ir bendradarbiavimą su dėstytoju (a 4), dèstytojo specialisto (dalykinę) kompetenciją (a 5), dèstytojo pedagogo (edukacinę) kompetenciją (a 6), vertinimo objektyvumą (a 7) ir vertinimo sistemos aiškumą (a 8) - laikysime lygiaverčiais, t. y. vienodai arba beveik vienodai veikiančius studentu igyjamas kompetencijas ir priklausančiais nuo dèstytojo, galima apskaičiuoti pasitenkinimo dèstytojo savybėmis rodikli $\mathrm{I}_{\mathrm{PD}}$ pagal formulę:

$$
\mathrm{I}_{\mathrm{PD}}=\frac{\left(\mathrm{I}_{\mathrm{P} 2}+\mathrm{I}_{\mathrm{P} 3}+\mathrm{I}_{\mathrm{P} 3}+\mathrm{I}_{\mathrm{P} 4}+\mathrm{I}_{\mathrm{P} 5}+\mathrm{I}_{\mathrm{P} 6}+\mathrm{I}_{\mathrm{P} 7}+\mathrm{I}_{\mathrm{P} 8}\right)}{7},
$$

čia $\mathrm{I}_{\mathrm{P} 2}$ - pasitenkinimo pratybų metu teikiamos informacijos pritaikomumu, $\mathrm{I}_{\mathrm{P} 3}$ - užsièmimų metu teikiamos informacijos naujumu, $\mathrm{I}_{\mathrm{P} 4}$ - bendravimu ir bendradarbiavimu su dèstytoju, $\mathrm{I}_{\mathrm{P} 5}$ - dèstytojo specialisto kompetencija, $\mathrm{I}_{\mathrm{P} 6}$ - dèsty- 


\begin{tabular}{|c|c|c|c|c|}
\hline \multirow{2}{*}{$\begin{array}{l}\text { Žymè- } \\
\text { jimas }\end{array}$} & \multirow[b]{2}{*}{ Požymis } & \multicolumn{2}{|l|}{ Faktorius } & \multirow[t]{2}{*}{$\begin{array}{l}3 \text { lentelè. Pasukta faktorių } \\
\text { matrica }\end{array}$} \\
\hline & & $\begin{array}{l}\text { Dalyko } \\
\text { savybès, \% }\end{array}$ & $\begin{array}{l}\text { Dėstytojo } \\
\text { savybės, \% }\end{array}$ & \\
\hline a 1 & Dėstomo dalyko aktualumas profesijai & 0,95 & 0,14 & \\
\hline a 2 & Užsièmimų metu pateikiamos informacijos pritaikomumas & 0,88 & 0,44 & \\
\hline a 3 & Užsièmimų metu pateikiamos informacijos naujumas & 0,76 & 0,54 & \\
\hline a 4 & Bendravimas ir bendradarbiavimas su dėstytoju & 0,34 & 0,88 & \\
\hline a 5 & Dėstytojo specialisto (dalykinè) kompetencija & 0,40 & 0,86 & \\
\hline a 6 & Dėstytojo pedagogo (edukacinè) kompetencija & 0,36 & 0,89 & \\
\hline a 7 & Vertinimo objektyvumas & 0,21 & 0,95 & \\
\hline a 8 & Vertinimo sistemos aiškumas & 0,26 & 0,93 & \\
\hline
\end{tabular}

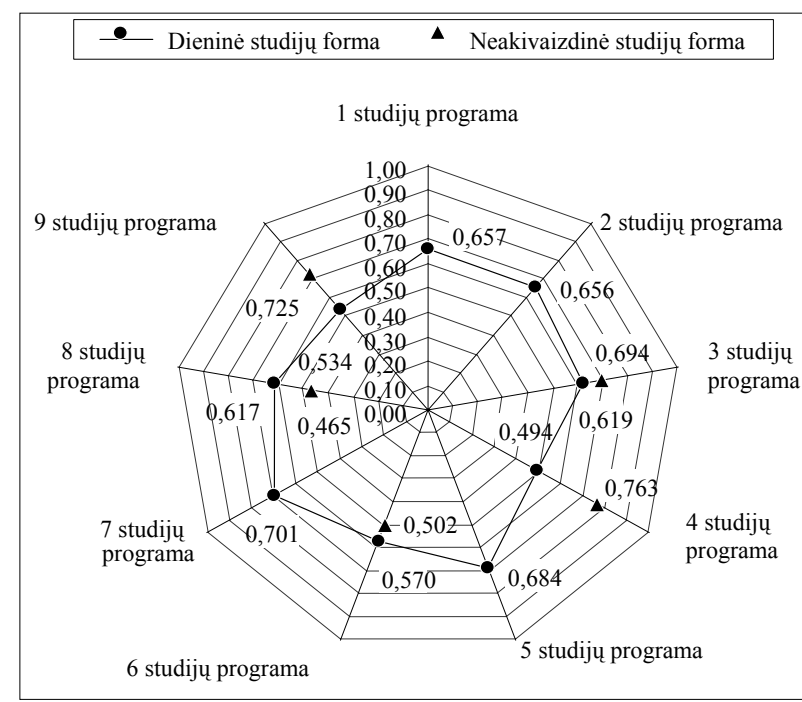

1 pav. Pasitenkinimo studijų dalykų dèstytojų savybėmis rodiklio $I_{P D}$ grafinis vaizdas pagal studiju programas

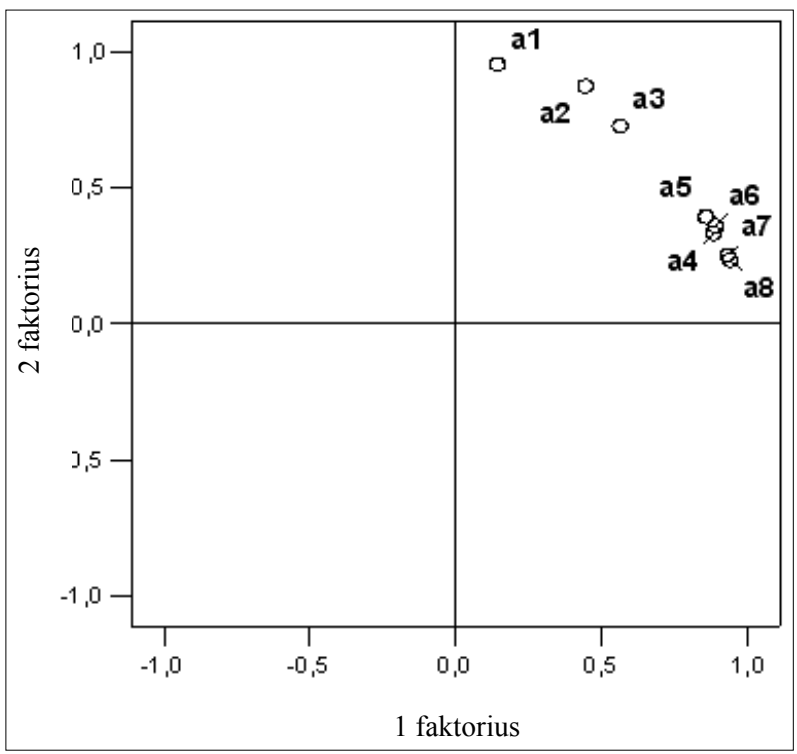

2 pav. Pasukta faktorių diagrama

tojo pedagogo kompetencija, $\mathrm{I}_{\mathrm{P} 7}$ - vertinimo objektyvumu, $\mathrm{I}_{\mathrm{P} 8}$ - vertinimo sistemos aiškumu rodikliai. Pasitenkinimo dėstytojo savybėmis rodiklio $\mathrm{I}_{\mathrm{PD}}$ interpretacija pateikiama 2 lentelèje.
Apibendrinta studentų nuomonè pagal pasirinktą rodikli I gali būti vaizduojama grafiškai. Pasitenkinimo studijų dalykų dėstytojų savybėmis rodiklio $I_{P D}$ grafinis vaizdas pagal studiju programas pateikiamas 1 paveiksle.

Interpretuojant studentų nuomonę, reikia vertinti tai, kad kuo rodiklio $I_{P D}$ vidurkis arčiau 1 (lūkesčiai patenkinti), tuo studentų pasitenkinimas studijų dalykų dėstytojų savybėmis yra aukštesnis ir atitinkamai - kuo šio rodiklio reikšmė arčiau 1 (lūkesčiai nepatenkinti), tuo studentu pasitenkinimas studijų dalykų dėstytojo savybėmis yra žemesnis. Šiuo pavyzdžiu dieninès studijų formos studentų nuomonę galima interpretuoti ir kaip daugiakampès figūros plotą. Kuo šis plotas didesnis, tuo aukštesnis atitinkamos studiju formos studentų pasitenkinimas studijų dalykų dėstytojų savybėmis.

Analizuodami standartizuotus tyrimo duomenis, atlikome faktorių analizę. Atrinkome bakalauro pakopos dieniniu studijų formos 132 dalykus ir jų desstytojus, t. y. tuos, apie kuriu dèstymo indikatorius išreiškè nuomonę ne mažiau kaip 20 respondentų, ir klasifikavome pagal kursą. Pirmą grupę sudare 39 dalykai ir jų dèstytojai, dèstę pirmo kurso studentams (1316 anketos), antra - 32 (1371 anketos), trečią - 30 (725 anketos), ketvirtą - 31 (795 anketos). Tas pats respondentas galèjo išsakyti nuomonę apie kelis studijų dalykus. Pirmos grupès dalykų rodiklių $\mathfrak{i}$ tolesnę faktoriu analizę neittraukème, kadangi manème, kad šie respondentai, mokydamiesi pirmame kurse, dar neidentifikavo savęs kaip studentų. Toliau analizavome antro, trečio ir ketvirto kurso studentu pasitenkinimo dèstymo indikatoriais duomenis. KMO and Bartlett's testo Kaiser-Meyer-Olkin imties adekvatumo koeficientas $0,856(\mathrm{p}=0,00)$ 


\begin{tabular}{|c|c|c|c|c|c|c|c|c|}
\hline \multirow[t]{28}{*}{$\begin{array}{l}4 \text { lentelè. Api- } \\
\text { b e n d r i n t i } \\
\text { LKKA baka- } \\
\text { lauro pakopos } \\
\text { studentu nuo- } \\
\text { monès tyrimo } \\
\text { rezultatai pa- } \\
\text { gal fakultetus }\end{array}$} & $\begin{array}{l}\text { Fakulteto } \\
\text { pavadi- } \\
\text { nimas }\end{array}$ & $\begin{array}{l}\text { Studijų } \\
\text { forma }\end{array}$ & $\begin{array}{l}\text { Respon- } \\
\text { dentų } \\
\text { skaičius }\end{array}$ & $\begin{array}{l}\text { Katedros } \\
\text { pavadinimas }\end{array}$ & $\begin{array}{l}\text { Dalyko } \\
\text { aktualumo } \\
\text { profesijai } \\
\text { rodiklis }\left(\mathrm{I}_{\mathrm{P} 1}\right)\end{array}$ & $\begin{array}{l}\text { Dalyko aktualumo } \\
\text { profesijai rodiklio } \\
\text { interpretacija }\end{array}$ & $\begin{array}{l}\text { Pasitenkinimo } \\
\text { dèstytojo } \\
\text { savybėmis } \\
\text { rodiklis }\left(\mathrm{I}_{\mathrm{PD}}\right)\end{array}$ & $\begin{array}{l}\text { Pasitenkinimo } \\
\text { dėstytojo } \\
\text { savybėmis } \\
\text { rodiklio inter- } \\
\text { pretacija }\end{array}$ \\
\hline & \multirow{7}{*}{1} & \multirow{4}{*}{ d } & 754 & 13 & 0,68 & Aukštas & 0,61 & Vidutinis \\
\hline & & & 710 & 14 & 0,60 & Vidutinis & 0,58 & Vidutinis \\
\hline & & & 416 & 15 & 0,92 & Aukštas & 0,78 & Aukštas \\
\hline & & & 1293 & 12 & 0,73 & Aukštas & 0,56 & Vidutinis \\
\hline & & \multirow{3}{*}{$\mathrm{n}$} & 53 & 12 & 0,56 & Vidutinis & 0,37 & Vidutinis \\
\hline & & & 63 & 13 & 0,50 & Vidutinis & 0,52 & Vidutinis \\
\hline & & & 33 & 14 & 0,68 & Aukštas & 0,65 & Vidutinis \\
\hline & \multirow{7}{*}{2} & \multirow{4}{*}{ d } & 505 & 1 & 0,69 & Aukštas & 0,66 & Vidutinis \\
\hline & & & 983 & 2 & 0,87 & Aukštas & 0,72 & Aukštas \\
\hline & & & 863 & 3 & 0,25 & Patenkinamas & 0,37 & Vidutinis \\
\hline & & & 202 & 4 & 0,71 & Aukštas & 0,62 & Vidutinis \\
\hline & & \multirow{3}{*}{$\mathrm{n}$} & 105 & 3 & 0,48 & Vidutinis & 0,61 & Vidutinis \\
\hline & & & 134 & 2 & 0,89 & Aukštas & 0,83 & Aukštas \\
\hline & & & 25 & 1 & 0,91 & Aukštas & 0,78 & Aukštas \\
\hline & \multirow{11}{*}{3} & \multirow{7}{*}{ d } & 311 & 5 & 0,74 & Aukštas & 0,79 & Aukštas \\
\hline & & & 212 & 6 & 0,81 & Aukštas & 0,75 & Aukštas \\
\hline & & & 362 & 7 & 0,52 & Vidutinis & 0,49 & Vidutinis \\
\hline & & & 965 & 8 & 0,72 & Patenkinamas & 0,65 & Vidutinis \\
\hline & & & 600 & 9 & 0,61 & Vidutinis & 0,61 & Vidutinis \\
\hline & & & 418 & 10 & 0,68 & Aukštas & 0,54 & Vidutinis \\
\hline & & & 154 & 11 & 0,88 & Aukštas & 0,85 & Aukštas \\
\hline & & \multirow{4}{*}{$\mathrm{n}$} & 25 & 10 & 0,32 & Patenkinamas & 0,41 & Vidutinis \\
\hline & & & 14 & 6 & 0,72 & Aukštas & 0,74 & Aukštas \\
\hline & & & 228 & 8 & 0,83 & Aukštas & 0,80 & Aukštas \\
\hline & & & 10 & 9 & 0,85 & Aukštas & 0,76 & Aukštas \\
\hline & \multirow{2}{*}{$\begin{array}{l}\text { Bendrasis } \\
\text { itvertinimas }\end{array}$} & d & 8748 & & 0,69 & Aukštas & 0,63 & Vidutinis \\
\hline & & $\mathrm{n}$ & 690 & & 0,67 & Vidutinis & 0,64 & Vidutinis \\
\hline
\end{tabular}

parode, kad turimi duomenys yra tinkami tirti faktoriu analizès metodu. Parinkus pagrindiniu faktoriu atrankos (Extraction Method: Principal Component Analysis) ir pasukimo metoda Varimax su Kaizerio normalizacija (Rotation Method: Varimax with Kaiser Normalization) buvo gauta pasukta faktoriu matrica (Rotated Component Matrix) (žr. 3 lent.) ir pasukta faktoriu diagrama (Component Plot in Rotated Space) (žr. 2 pav.).

Remdamiesi pasukta faktorių matrica, išskyrème du faktorius: pirma - dèstytojo savybes (faktorius sudaro $74 \%$ suminès dispersijos) ir antra - dalyko savybes (faktorius sudaro 16\% suminès dispersijos).

Pasuktoje faktoriu matricoje (žr. 3 lent.) matyti, kad pirmam faktoriui priskiriami požymiai: a 1 - dèstomo dalyko aktualumas profesijai (koreliacija 0,954$)$, a 2 - užsièmimu metu pateikiamos informacijos pritaikomumas (koreliacija
0,876 ) ir a 3 - pratybu metu pateikiamos informacijos naujumas (koreliacija 0,756). Antram faktoriui priskiriami požymiai: a 4 - bendravimas ir bendradarbiavimas su dèstytoju ( koreliacija 0,884 ), a 5 - déstytojo specialisto (dalykinè) kompetencija (koreliacija 0,856 ), a 6 - desstytojo pedagogo (edukacinè) kompetencija (koreliacija 0,889 ), a 7 - vertinimo objektyvumas (koreliacija 0,947$)$ ir a 8 - vertinimo sistemos aiškumas (koreliacija 0,930).

Gautų faktorių duomenys - dèstytojo savybès ir dalyko savybès - buvo perkoduoti (suskirstyti kvartiliais) ir paruošti asociacinei analizei $\chi^{2}$. Atlikus asociacinę analizę, buvo nustatyta statistiškai reikšminga silpna atvirkštinè priklausomybè ( Gamma $=-0,352, p=0,01)$ tarp dèstytojo savybių ir studento studiju programos (MantelHanzel testas, $\mathrm{p}=0,00)$. Dalyko savybiu ryšys su studento studijų programa nepastebetas. 


\begin{tabular}{|c|c|c|c|c|c|c|c|}
\hline $\begin{array}{l}\text { Studijų } \\
\text { programa }\end{array}$ & $\begin{array}{l}\text { Studijų } \\
\text { forma }\end{array}$ & $\begin{array}{l}\text { Respondentų } \\
\text { skaičius }\end{array}$ & $\begin{array}{l}\text { Dalyko } \\
\text { aktualumo } \\
\text { profesijai } \\
\text { rodiklis }\left(\mathrm{I}_{\mathrm{P} 1}\right)\end{array}$ & $\begin{array}{l}\text { Dalyko aktu- } \\
\text { alumo profesijai } \\
\text { rodiklio inter- } \\
\text { pretacija }\end{array}$ & $\begin{array}{l}\text { Pasitenkinimo } \\
\text { dėstytojo } \\
\text { savybėmis } \\
\text { rodiklis }\left(\mathrm{I}_{\mathrm{PD}}\right)\end{array}$ & $\begin{array}{l}\text { Pasitenki- } \\
\text { nimo dėstytojo } \\
\text { savybėmis rodiklio } \\
\text { interpretacija }\end{array}$ & $\begin{array}{l}5 \text { lentelè. Apiben- } \\
\text { drinti LKKA ba- } \\
\text { kalauro pakopos } \\
\text { studentų nuomonès } \\
\text { tyrimo rezultatai } \\
\text { pagal studijų pro- } \\
\text { gramas }\end{array}$ \\
\hline 1 & $\mathrm{~d}$ & 1495 & 0,75 & Aukštas & 0,67 & Vidutinis & \\
\hline 2 & $\mathrm{~d}$ & 563 & 0,70 & Aukštas & 0,65 & Vidutinis & \\
\hline \multirow{2}{*}{3} & $\mathrm{~d}$ & 1058 & 0,69 & Aukštas & 0,65 & Vidutinis & \\
\hline & $\mathrm{n}$ & 71 & 0,67 & Vidutinis & 0,56 & Vidutinis & \\
\hline \multirow{2}{*}{4} & $\mathrm{~d}$ & 910 & 0,43 & Vidutinis & 0,49 & Vidutinis & \\
\hline & $\mathrm{n}$ & 152 & 0,76 & Aukštas & 0,77 & Aukštas & \\
\hline 5 & $\mathrm{~d}$ & 253 & 0,83 & Aukštas & 0,70 & Aukštas & \\
\hline \multirow{2}{*}{6} & $\mathrm{~d}$ & 856 & 0,63 & Vidutinis & 0,57 & Vidutinis & \\
\hline & $\mathrm{n}$ & 119 & 0,55 & Vidutinis & 0,51 & Vidutinis & \\
\hline 7 & $\mathrm{~d}$ & 954 & 0,77 & Aukštas & 0,71 & Aukštas & \\
\hline \multirow{2}{*}{8} & $\mathrm{~d}$ & 1358 & 0,71 & Aukštas & 0,66 & Vidutinis & \\
\hline & $\mathrm{n}$ & 99 & 0,58 & Vidutinis & 0,60 & Vidutinis & \\
\hline \multirow{2}{*}{9} & $\mathrm{~d}$ & 1301 & 0,67 & Vidutinis & 0,54 & Vidutinis & \\
\hline & $\mathrm{n}$ & 249 & 0,79 & Aukštas & 0,78 & Aukštas & \\
\hline \multirow{2}{*}{$\begin{array}{l}\text { Bendrasis } \\
\text { ivertinimas }\end{array}$} & $\mathrm{d}$ & 8748 & 0,69 & Aukštas & 0,63 & Vidutinis & \\
\hline & $\mathrm{n}$ & 690 & 0,67 & Vidutinis & 0,64 & Vidutinis & \\
\hline
\end{tabular}

\section{REZULTATAI}

Apibendrinant studentų nuomonę apie dalykų dèstymo kokybę, kiekvienam studijų dalykui ir jo dèstytojui dalyko aktualumo profesijai rodiklis $\mathrm{I}_{\mathrm{P} 1}$ ir pasitenkinimo dèstytojo savybèmis rodiklis $I_{P D}$ buvo apskaičiuojamas tik tada, jei savo nuomonę išsakè ne mažiau kaip 5 respondentai. Apibendrinti LKKA bakalauro pakopos studentų nuomonès tyrimo rezultatai pagal fakultetus pateikiami 4 lentelèje, o pagal studijų programas - 5-oje.

\section{REZULTATUQ APTARIMAS}

Naudojantis sukurta metodologija nustatyta ir interpretuota LKKA dieninių, neakivaizdiniu studijų bakalauro pakopos I-IV kurso studentu nuomoné apie $2005-2006 \mathrm{~m}$. m. studijuotu dalykų dèstymo kokybès indikatorius. Studijų dalyku aktualumo profesijai $\left(\mathrm{I}_{\mathrm{P} 1}\right)$ ir pasitenkinimo destytojo savybèmis $\left(\mathrm{I}_{\mathrm{PD}}\right)$ rodikliai gali būti naudojami atskirų studijų dalykų dèstymui ịvertinti, tačiau turi būti išanalizuotas jų santykis su kitų to paties dalyko dèstytojų dèstomų dalykų rodikliais, ir jis igauna prasmę tik tada, kai naudojamas kaip priemonè desstymo procesui tobulinti.

Nagrinėdami faktorių analizès rezultatus, atkreipème dèmesi i tai, kad požymiu a 2 (užsièmimu metu pateikiamos informacijos pritai- komumo) ir a 3 (užsièmimu metu pateikiamos informacijos naujumo) koreliacija su déstytojo savybėmis yra reikšminga (a 2 koreliacija 0,44 ; a 3 koreliacija 0,54), tačiau mažesnè nei šiuc požymių koreliacija su dalyko savybèmis (a 2 koreliacija 0,88 ; a 3 koreliacija 0,76 ). Tai rodo, kad desstytojai turètų daugiau démesio kreipti $\mathfrak{i}$ šiuos dèstymo kokybės indikatorius: pateikiamos informacijos pritaikomumą (a 2) ir pateikiamos informacijos naujumą (a 3 ).

Apibendrinant studentu nuomonès tyrimų duomenis, daugelio Lietuvos tyrèjų darbuose dažnai apsiribojama procentiniais skirstiniais, o duomenys neapibendrinami. Naudojantis pateikiama metodologija, galima ne tik apibendrinti studentu nuomonę, bet ir analizuoti priklausomybę, palyginti pagal ịvairias kategorijas.

Nagrinejjant studentų nuomonę, reikètų atsižvelgti i 1997 m. Didžiosios Britanijos Aukštojo mokslo nacionalinio komiteto tyrimo „Aukštasis išsilavinimas besimokančioje visuomenejje" ataskaita. Joje pastebèta, kad tiriant studentu siekius, lūkesčius ir nuomonę apie dèstytojus, vertinimai yra aukštesni (padidinti) ir išsiskiria iš kitų sričių vertinimų. Tokia tendencija gal būdinga ir kitų šalių studentams, tačiau norint patikrinti šią hipotezę reikia atlikti lyginamaji tyrima.

Organizuojant studentų nuomonės tyrimą, reikètų atsižvelgti i tai, kad studentai, tiesiogiai dalyvaujantys studiju procese, yra suinte- 
resuota puse, turinti labiausiai pagristą, bet ir subjektyviausią nuomonę. Studentų nuomonè nèra vienintelis studijų dalykų dèstymo kokybès vertinimo elementas. Studentai studiju procesa vertina remdamiesi momentine patirtimi, nemato platesnès perspektyvos ir negali aprèpti visumos (Valiuškevičiūtè ir kt., 2004; Patry, Gastager, 2004). Tačiau nagrinejjant kokybę vartotoju poreikių bei lūkesčiu tenkinimo aspektu, šią nuomonę būtina tirti ir atsižvelgti $\mathfrak{i}$ tai, kad vartotojo pasitenkinimą dèstymo kokybe lemia paslaugos teikejjo pastangos.

\section{IŠVADA}

Studentų nuomonès apie studijų dalykų dèstymo kokybę tyrimo duomenu vertinimo instrumento metodologinis pagrindimas atliktas statistiniais metodais. Studentų nuomonès interpretavimas naudojant balinę skalę, duomenų standartizavimas ir asociacinè analizè leidžia apibendrinti duomenis pagal ivairias kategorijas - šio tyrimo atveju pagal studijų formas, katedras ir kursą. Studijų dalykų aktualumo profesijai $I_{P 1}$ ir pasitenkinimo dèstytojo savybèmis $\mathrm{I}_{\mathrm{PD}}$ rodikliai gali būti naudojami atskiru studiju dalykų desstymo kokybei vertinti, tačiau jie turi būti nagrinèjami kartu su kitų to paties dalyko dėstytojų dėstomų dalykų rodikliais ir igauna prasmę tik tada, kai naudojami kaip priemoné dèstymo procesui tobulinti. Tyrimo duomenų faktorių analizè leido išskirti du dèstymo kokybès faktorius: pirmą - dalyko savybes (16\% suminès dispersijos), antrą — dèstytojo savybes ( $74 \%$ suminès dispersijos). Atlikus asociacinę analizę, nustatyta statistiškai reikšminga silpna atvirkštinè priklausomybè (Gamma $=-0,352 ; p=0,01)$ tarp dèstytojo savybių ir studento studiju programos (Mantel-Hanzel testas, $\mathrm{p}=0,00$ ).

\section{LITERATŪRA}

A Memorandum of Lifelong Learning. (2000). European Council, Brussels, 30 October.

European Association for Quality Assurance in Higher Education (ENQA). (2005). Standards and Guidelines for Quality Assurance in the European Higher Education Area. Helsinki.

European University Association. (2005). Developing an Internal Quality Culture in European Universities: Report on the Quality Culture Project 2002-2003. Brussels.

Higher education in the learning society. (1997). Report of the National committee.

Kardelis, K. (1997). Moksliniu tyrimu metodologija ir metodai. Kaunas: Technologija.

Lipinskienè, D. (2002). Edukacinè studenta igalinanti studijuoti aplinka: daktaro disertacija. Kaunas: KTU.

Patry, J. L., Gastager, A. (2004). Kokybès vertinimo dilemos. Aukštojo mokslo kokybe, 1, 60-79.

Stake, R. E., Cisneros-Cohernour, E. J. (2004). Dėstymo kokybė aukštojoje mokykloje. Aukštojo mokslo kokybe, 1, 94-117.

Valiuškevičiūtė, A., Druskytè, I., Mikutavičienė, I. (2004). Universitetinių studijų kokybès vertinimas: akademinès bendruomenès požiūris. Aukštojo mokslo kokybè, 1, 3859.

Don Westerheijden, F. (2005). Judančio taikinio link: aukštojo mokslo kokybės užtikrinimas Europoje. Aukštojo mokslo kokybè, 2, 52-71.

Želvys, R., Žilinskaitè, R. (2005). Studijų reformų Lietuvoje analizè. Aukštojo mokslo kokybè, 2, 25-32.

Бююль, А., Цёфель, П. (2002). SPSS: искусство обработки информации. Санкт-Петербург: ДиаСофтЮП.

Захарова, И. В., Стрюкова, Г. А. (1999). Семантический дифференциал как метод диагностики восприятия учащимся педагога. Психологическая наука и образование, $3-4$.

Паниотто, В. И., Максименко, В. С. (2003). Количественные методы в социологических исследованиях. Киев. Prieiga per internetą: http://www.ecsocman.edu. $\mathrm{ru} / \mathrm{db} / \mathrm{msg} / 77144 . \mathrm{html}$

Таранов, Д. (2005). SPSS: статистический анализ в маркетинговых исследованиях. Санкт-Петербург: Питер Принт. 


\title{
METHODOLOGICAL SUBSTANTIATION OF SURVEY INSTRUMENT FOR STUDENTS' OPINION ABOUT TEACHING QUALITY
}

\author{
Giedrė Judita Rastauskienė, Ina Marija Šeščilienė, Ilona Tilindienė \\ Lithuanian Academy of Physical Education, Kaunas, Lithuania
}

\begin{abstract}
In this article the authors present the results of the investigation of students' attitudes towards the teaching quality in the Lithuanian Academy of Physical Education. The aim of the study was to substantiate the survey instrument for permanent and massive inquiries about teaching quality and its indicators by means of statistical methods. Interpretation of students' judgements was carried out using range scale, standardization of data and factor analysis, which allowed discerning two factors of teaching quality. The first factor included the characteristics of the studied subject and the second one - personal characteristics of the teacher of the same subject. Results of analysis of indicators of professional relevance and satisfaction with characteristics of the teacher could be used for the evaluation of particular subjects, but they must be considered only as an implement for the improvement of the teaching quality.

1077 full time and part time bachelor students were inquired about teaching the study subjects in the school year of 2005-2006. As there are a lot of approaches to the meaning of what the teaching quality is and what indicators reveal it, we examined and discussed the subjective contentment of bachelor students only according to those indicators which apparently influence students' competencies. The authors do not claim to reveal the thorough state of the teaching quality in LAPE, but our data enable us to analyse and interpret students' opinions about teaching quality indicators which are still under consideration and to outline some aspects of the teaching quality. The results of the study also capacitated verifying the survey instrument and suggesting a rare and original method of data analysis. The authors also expect discussion about the teaching quality in the academic community of the university.
\end{abstract}

Keywords: teaching quality, quality indicators, methodology of teaching quality research.

Gauta 2007 m. vasario 12 d.

Received on February 12, 2007

Priimta $2007 \mathrm{~m}$. balandžio $24 \mathrm{~d}$

Accepted on April 24, 2007
Giedrè Judita Rastauskienè

Lietuvos kūno kultūros akademija

(Lithuanian Academy of Physical Education)

Sporto g. 6, LT-44221 Kaunas

Lietuva (Lithuania)

E-mail g.rastauskiene@lkka.lt

Tel +370 37302668 